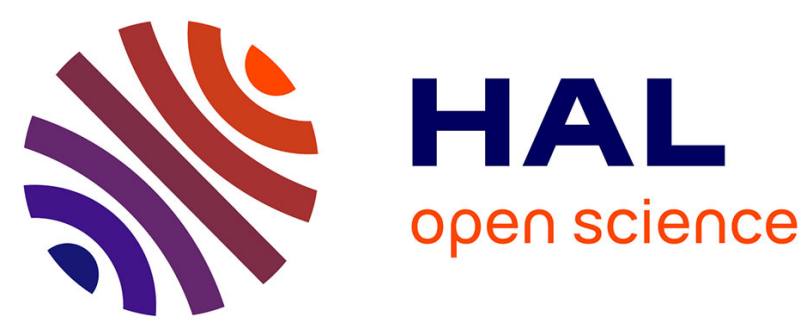

\title{
Thermal expansion of chromium-rich iron-based or iron /nickel-based alloys reinforced by tantalum carbides
}

\author{
P. Berthod, L. Aranda, Y. Hamini
}

\section{To cite this version:}

P. Berthod, L. Aranda, Y. Hamini. Thermal expansion of chromium-rich iron-based or iron /nickel-based alloys reinforced by tantalum carbides. Materials Science, 2011, 47 (3), pp.319-326. 10.1007/s11003-011-9399-0 . hal-02538655

\section{HAL Id: hal-02538655 \\ https://hal.science/hal-02538655}

Submitted on 9 Apr 2020

HAL is a multi-disciplinary open access archive for the deposit and dissemination of scientific research documents, whether they are published or not. The documents may come from teaching and research institutions in France or abroad, or from public or private research centers.
L'archive ouverte pluridisciplinaire HAL, est destinée au dépôt et à la diffusion de documents scientifiques de niveau recherche, publiés ou non, émanant des établissements d'enseignement et de recherche français ou étrangers, des laboratoires publics ou privés. 


\title{
THERMAL EXPANSION OF CHROMIUM-RICH IRON-BASED OR IRON /NICKEL-BASED ALLOYS REINFORCED BY TANTALUM CARBIDES \\ P. BERTHOD, L. ARANDA, AND Y. HAMINI
}

\author{
Institut Jean Lamour, Faculty of Sciences and Techniques, Nancy, France \\ Postprint version of the article Materials Science, Vol. 47, No. 3, November, 2011 \\ (Ukrainian Original Vol. 47, No. 3, May-June, 2011) \\ DOI: https://doi.org/10.1007/s11003-011-9399-0
}

Six alloys reinforced by $\mathrm{TaC}$ carbides based on iron (ferritic) or both iron and nickel (austenitic) were studied in thermal expansion between 100 and $1200^{\circ} \mathrm{C}$ for two microstructure orientations. The heating, isothermal and cooling parts of the dilatometry curves were characterized. The thermal expansion of the ferritic alloys is less important than for the austenitic alloys. A compressive deformation of matrix subjected to stresses applied by the carbides network was observed. The importance of this phenomenon seems depending more on the matrix nature than on the microstructure orientation.

Keywords: thermal expansion, chromium-rich iron based alloy, tantalum carbides.

An increase in temperature induces a geometrical expansion for most materials, especially for the metallic alloys, with as consequences the possible development of internal stresses when they are not free to deform or when the whole considered piece is not homogeneous in temperature. This is particularly true for refractory alloys and superalloys the temperature of which can vary between room temperature and more than $1000^{\circ} \mathrm{C}$ [1] in service. To minimize such stresses appearing when temperature varies significantly, one usually looks for lowering the Young's modulus or the average thermal expansion coefficient of materials. Several parameters can influence the thermal expansion of an alloy: its chemical composition, the natures and volume fractions of the phases present in its microstructure (if their thermal expansion behaviours are different from one another), and possibly the local microstructure orientation in the case of foundry alloys.

The aim of this work is to study the possible effects of these three parameters on the thermal expansion of selected metallic alloys which are especially refractory and which can be candidates for uses at high temperatures in corrosive environments.

Materials and methods. Three iron-based alloys and three $\{$ iron+nickel $\}$-based alloys, all containing about $30 \mathrm{wt}$ \% Cr but various amounts of Ta and $\mathrm{C}$, were elaborated by High Frequency induction foundry (around $100 \mathrm{~g}$ for each ingot), from pure elements. Their obtained chemical compositions are given in Table 1 (obtained contents, measured by Energy Dispersion Spectrometry), while their microstructures are illustrated by several micrographs and X-Ray Diffraction patterns in Figs. 1 and 2 (Scanning Electron Microscope Philips XL30, Back Scattered Electrons mode, accelerating voltage of 20kV; Bruker XPERT-Pro Diffractometer). These are composed of a bccferritic (respectively fcc-austenitic) matrix of $\mathrm{Fe}$ (resp. $\mathrm{Fe}+\mathrm{Ni}$ ) containing the other elements in solid solution (almost all $\mathrm{Cr}$ and a part of Ta and of $\mathrm{C}$ ), and of carbides. These ones are almost exclusively $\mathrm{TaC}$ carbides in the FeTa1, FeTa3, FeNiTa1 and FeNiTa3 alloys, while chromium carbides are also present (in very small quantities) in the FeTa2 and FeNiTa2 alloys, in addition to the TaC. The TaC carbides are the most present in all alloys, essentially in the interdendritic spaces where they constitute a network, continuous in some of the alloys. Such alloys were previously studied from the thermodynamic point of view in earlier works $[2,3]$.

Corresponding author. P. BERTHOD, e-mail: pberthodcentralelille1987@orange.fr 
Table 1. Chemical compositions of the studied cast alloys (EDS ${ }^{*}$ measurements, average $\pm 1 \sigma ; 3^{* * *}$ to $6^{* * * *}$ locations at $\times 250$ )

\begin{tabular}{|c|c|c|c|c|c|c|}
\hline Alloys & weight $\%$ & $\mathrm{Fe}$ & $\mathrm{Ni}$ & $\mathrm{Cr}$ & $\mathrm{C}$ & $\mathrm{Ta}$ \\
\hline \multirow{3}{*}{$\begin{array}{c}\text { Based on } \\
\mathrm{Fe}^{* * *}\end{array}$} & $\mathrm{FeTa} 1$ & bal. & $/$ & $29.8 \pm 0.7$ & 0.2 & $2.1 \pm 0.5$ \\
\cline { 2 - 7 } & $\mathrm{FeTa} 2$ & bal. & $/$ & $29.5 \pm 2.7$ & 0.4 & $2.4 \pm 0.4$ \\
\cline { 2 - 7 } & $\mathrm{FeTa} 3$ & bal. & $/$ & $29.2 \pm 1.6$ & 0.4 & $6.2 \pm 1.1$ \\
\hline $\begin{array}{c}\text { Based on } \\
\text { Fe and } \\
\mathrm{Ni}^{* * *}\end{array}$ & FeNiTa1 & bal. & $34.2 \pm 0.5$ & $29.6 \pm 0.3$ & 0.2 & $2.9 \pm 0.3$ \\
\cline { 2 - 7 } & FeNiTa2 & bal. & $34.0 \pm 0.4$ & $30.0 \pm 0.3$ & 0.4 & $2.8 \pm 0.4$ \\
\cline { 2 - 7 } & FeNiTa3 & bal. & $32.5 \pm 0.2$ & $29.5 \pm 0.3$ & 0.4 & $6.4 \pm 0.3$ \\
\hline
\end{tabular}

${ }^{*}$ EDS: Energy dispersion spectrometry.
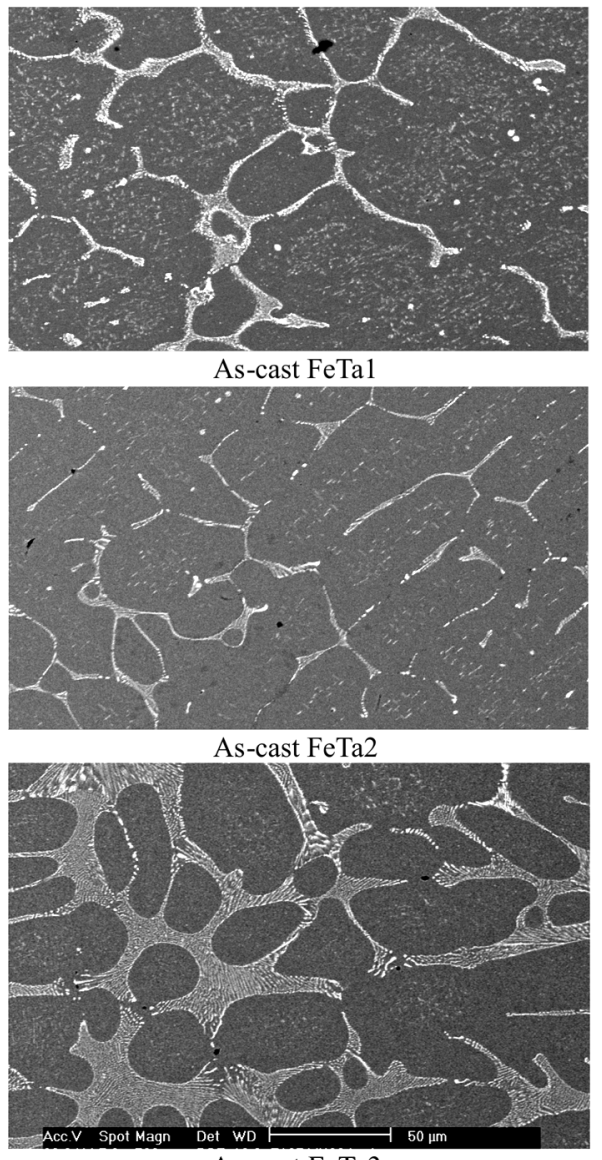

As-cast FeTa3
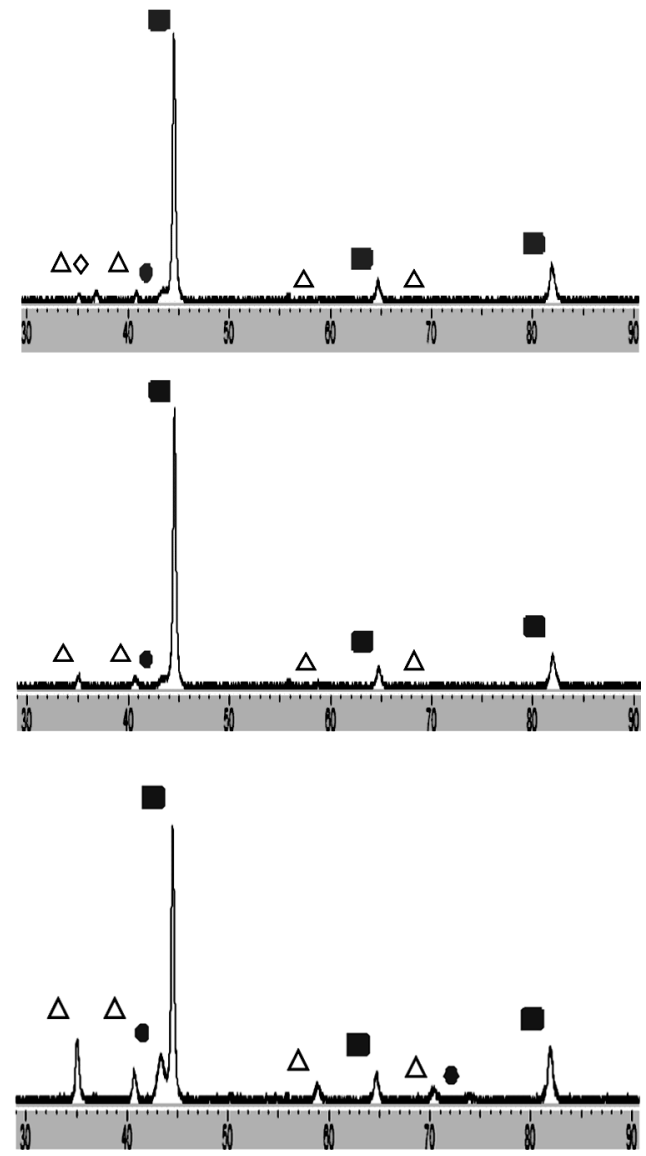

Fig. 1. Microstructures of the three alloys based on $\mathrm{Fe}\left(\mathrm{SEM}^{*}\right.$ in $\mathrm{BSE}^{* *}$ mode, $\mathrm{XRD}^{* * *}$ patterns).

( ${ }^{*}$ SEM: Scanning electron microscope; ${ }^{* *}$ BSE: Back scattered electrons; ${ }^{* * *}$ XRD: X-Ray diffraction): $\mathbf{\square}$ - bcc (matrix); - fcc (matrix); $\triangle-\mathrm{TaC} ; \diamond-\mathrm{Ta}_{2} \mathrm{C}$.

The samples, parallelepipeds of about $4 \mathrm{~mm} \times 4 \mathrm{~mm} \times 2.5 \mathrm{~mm}^{*}\left(^{*}:\right.$ direction of the measured dilatation), were cut in the ingot following two procedures. These ones allowed studying the thermal expansion in the direction of the thermal gradient existing during solidification, or in the direction perpendicular to this thermal gradient under solidification (Fig. 3), as is to say globally in directions respectively parallel and perpendicular to the primary dendritic arms [4]. The thermal expansion was measured 
using a Setaram TMA 92-16.18 apparatus during heating at room temperature up to $1200^{\circ} \mathrm{C}$ (rate of $10 \mathrm{~K} \times \mathrm{min}^{-1}$ ), at the 10 minutes-isothermal stage at $1200^{\circ} \mathrm{C}$ and during cooling (rate of $-20 \mathrm{~K} \times \mathrm{min}^{-1}$ ). Only the parts of the curves above $100^{\circ} \mathrm{C}$ were considered since the thermal equilibrium of the apparatus was achieved only after heating over this temperature.
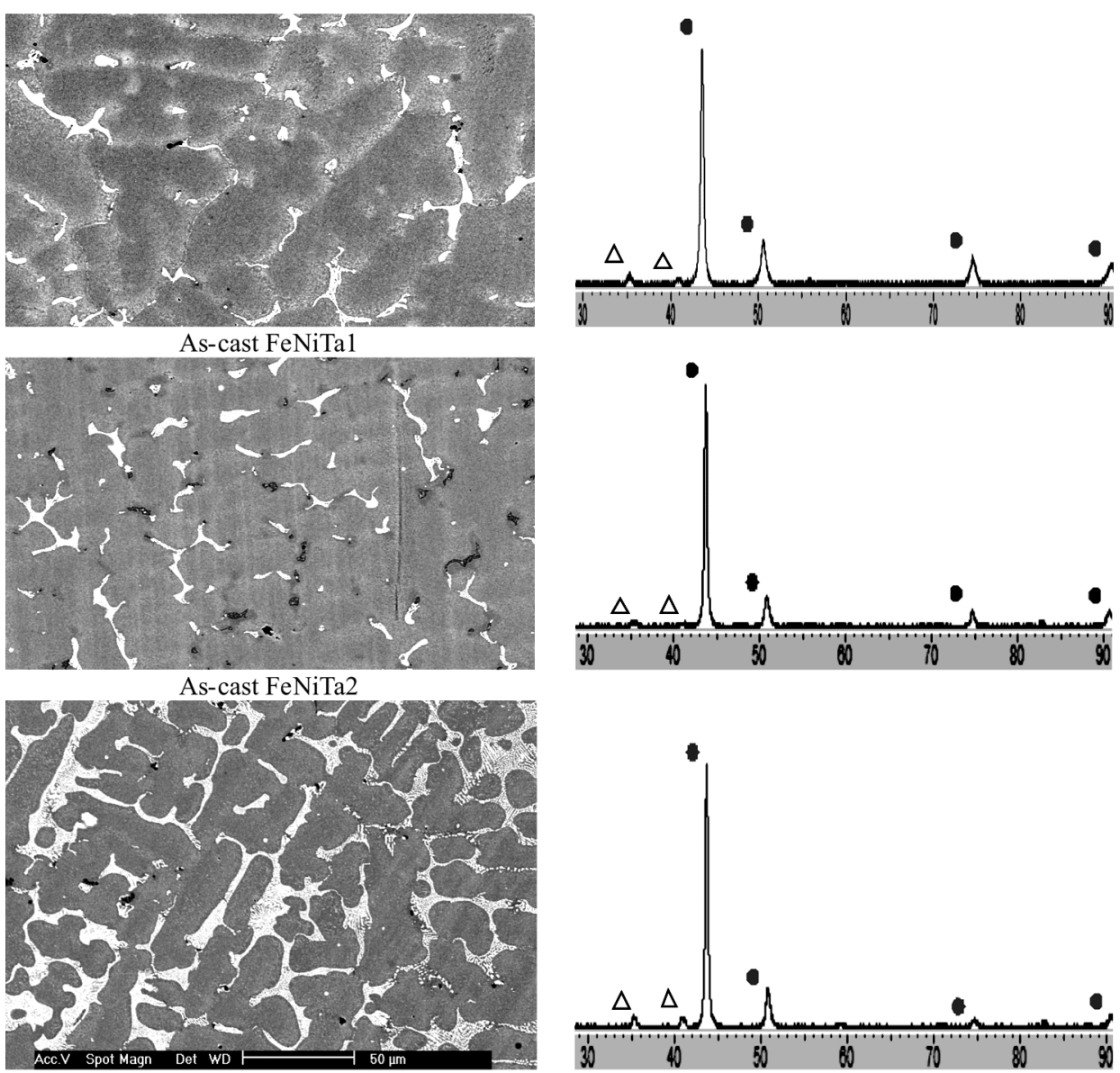

As-cast FeNiTa3

Fig. 2. Microstructures of the three alloys based on both Fe and Ni (SEM in BSE mode, XRD patterns): - fcc (matrix); $\triangle-$ TaC.

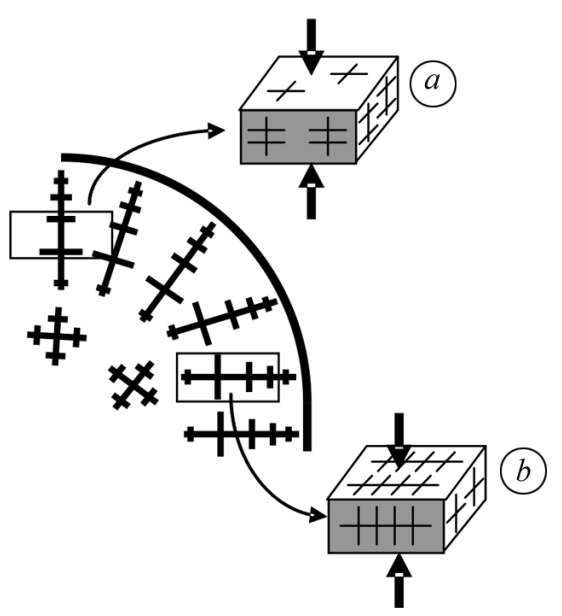

Fig. 3. The two cutting modes used to obtain samples for the study of thermal expansion following the two orientations to the thermal gradient during solidification. $a$ - parallel; $b$ - perpendicular.

Results and discussion. The obtained dilatometry curves are presented in Fig. 4. The heating parts are distinguished from the cooling parts while the isothermal parts, not represented, are simply vertical lines joining the extremities of the two latter ones, in each case. 
One can first notice that the thickness of all samples effectively increases with temperature (at least on the greatest part of the curves), without any discontinuities, according to the absence of any crystallographic change for the matrix over this temperature range. Indeed the FeTa alloys are initially and remain ferritic and the FeNiTa alloys - austenitic [2,3]. Secondly, except for the FeNiTa1 alloy (parallel and perpendicular) and for the FeNiTa3 alloy (parallel), and also maybe at the FeNiTa2 alloy (perpendicular), there is generally a deceleration of the elongation for the highest temperatures. In some cases a beginning of contraction can appear before reaching $1200^{\circ} \mathrm{C}$ (e.g. FeTa3 for the two orientations), which goes on at the isothermal stage. This leads to both a cooling-part of the dilatometry curve which is clearly bellow the heating part and a final contraction of the sample after return to $100^{\circ} \mathrm{C}$ and to room temperature. Indeed, except for the alloys FeNiTa1, FeNiTa2 (perpendicular only) and FeNiTa3 (parallel only), all the thicknesses at $100^{\circ} \mathrm{C}$ are lower after dilatometry experiment than before (negative deformations).
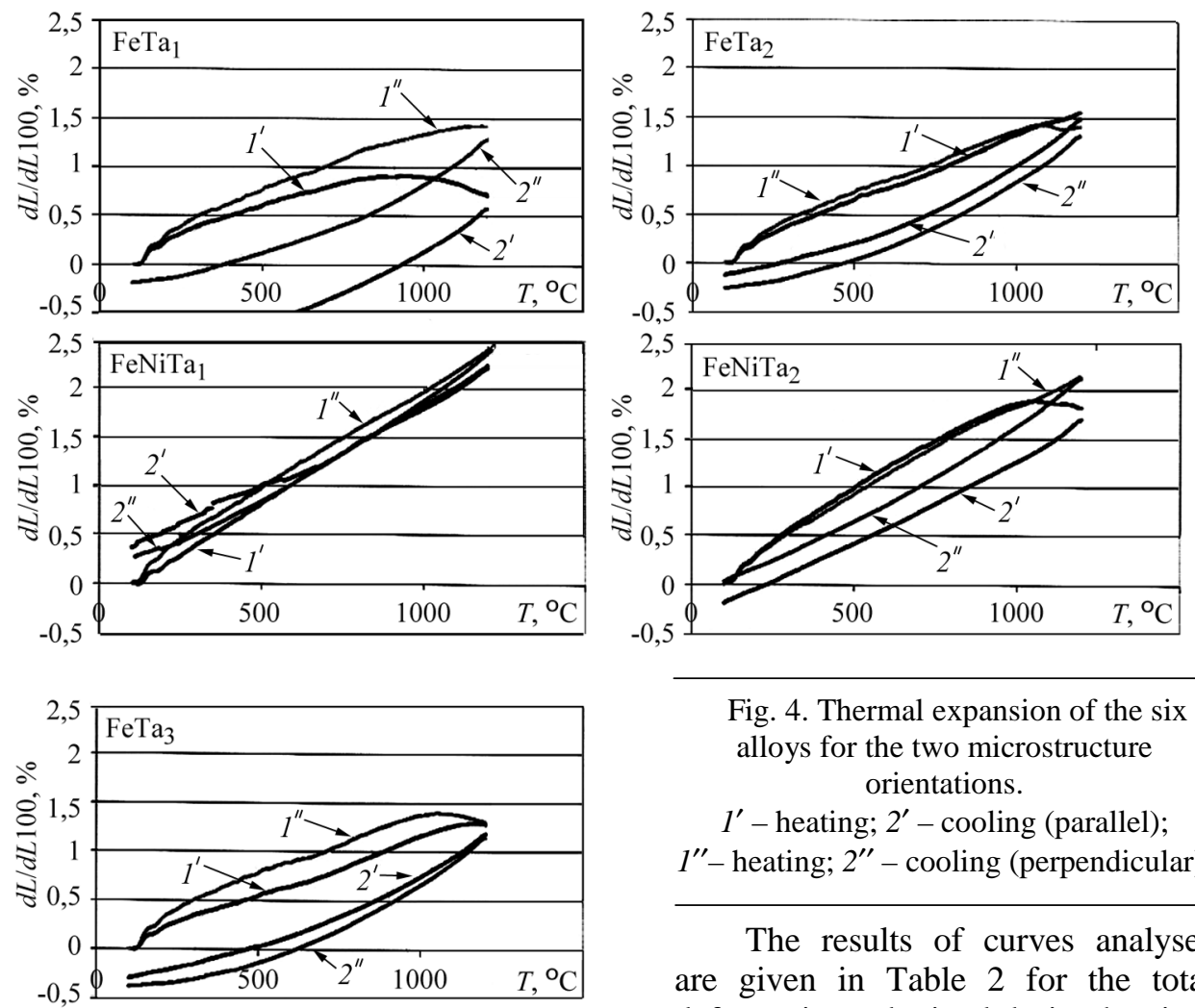

Fig. 4. Thermal expansion of the six alloys for the two microstructure orientations.

$1^{\prime}$ - heating; $2^{\prime}-$ cooling (parallel); $1^{\prime \prime}$ - heating; $2^{\prime \prime}$ - cooling (perpendicular).

The results of curves analyses are given in Table 2 for the total deformations obtained during heating,

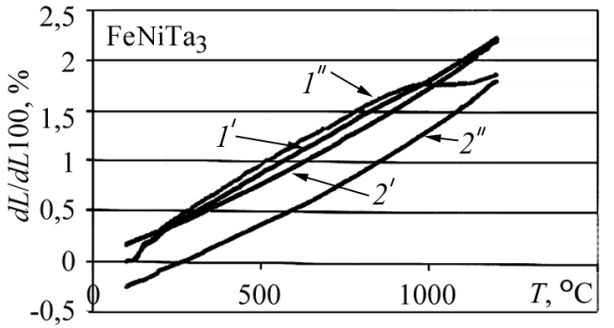
isothermal dwell or cooling, and in Table 3 for the average thermal coefficients at heating and cooling determined over the temperatures range $\left(250^{\circ} \mathrm{C} ; 750^{\circ} \mathrm{C}\right)$ in which most of the thermal expansions or contractions can be considered as almost linear. It appears that the thermal expansion and the thermal contraction between 100 and $1200^{\circ} \mathrm{C}$ are almost equal for each alloy, without real effect of the orientation. In contrast the isothermal negative deformation at $1200^{\circ} \mathrm{C}$ tends to be more severe for the perpendicular case than for the parallel case (except for only FeNiTa2), which can be logically found again with the average rates 
of isothermal contraction given in Table 3. There is also a global difference in total thermal expansion or contraction between all the ferritic alloys and all the austenitic alloys: the first ones generally display slow thermal expansion or contraction and high isothermal negative deformation or contraction rates by comparison with the latter alloys.

Table 2. Deformations during heating, at the isothermal stage and during cooling

\begin{tabular}{|c|c|c|c|}
\hline \multirow{4}{*}{ Alloy } & \multirow{2}{*}{$/ /$} & $\Delta \varepsilon_{100 \rightarrow 1200}(\%)$ & \multirow{2}{*}{$\Delta \varepsilon_{T=1200}(\%)$} \\
\hline & & $\Delta \varepsilon_{1200 \rightarrow 1000}(\%)$ & \\
\hline & \multirow{2}{*}{+} & $\Delta \varepsilon_{100 \rightarrow 1200}(\%)$ & \multirow{2}{*}{$\Delta \varepsilon_{T=1200}(\%)$} \\
\hline & & $\Delta \varepsilon_{1200 \rightarrow 1000}(\%)$ & \\
\hline \multirow{4}{*}{ FeTa1 } & \multirow{2}{*}{$/ /$} & 0.71 & \multirow{2}{*}{-0.132} \\
\hline & & -1.47 & \\
\hline & \multirow{2}{*}{+} & 1.42 & \multirow{2}{*}{-0.137} \\
\hline & & -1.48 & \\
\hline \multirow{4}{*}{ FeTa2 } & \multirow{2}{*}{$/ /$} & 1.55 & \multirow{2}{*}{-0.072} \\
\hline & & -1.60 & \\
\hline & \multirow{2}{*}{+} & 1.41 & \multirow{2}{*}{-0.094} \\
\hline & & -1.57 & \\
\hline \multirow{4}{*}{ FeTa3 } & \multirow{2}{*}{ // } & 1.29 & \multirow{2}{*}{-0.103} \\
\hline & & -1.48 & \\
\hline & \multirow{2}{*}{+} & 1.27 & \multirow{2}{*}{-0.125} \\
\hline & & -1.53 & \\
\hline \multirow{4}{*}{ FeNiTa1 } & \multirow{2}{*}{$/ /$} & 2.24 & \multirow{2}{*}{-0.019} \\
\hline & & -1.86 & \\
\hline & \multirow{2}{*}{+} & 2.40 & \multirow{2}{*}{-0.036} \\
\hline & & -2.10 & \\
\hline \multirow{4}{*}{ FeNiTa2 } & \multirow{2}{*}{ // } & 1.82 & \multirow{2}{*}{-0.123} \\
\hline & & -1.90 & \\
\hline & \multirow{2}{*}{+} & 2.15 & \multirow{2}{*}{-0.032} \\
\hline & & -2.09 & \\
\hline \multirow{4}{*}{ FeNiTa3 } & \multirow{2}{*}{$/ /$} & 2.22 & \multirow{2}{*}{-0.029} \\
\hline & & -2.03 & \\
\hline & \pm & 1.87 & 0066 \\
\hline & + & -2.05 & -0.000 \\
\hline
\end{tabular}

Concerning the average coefficients of thermal expansion or contraction (Table 3), it can be noticed that the coefficient is higher for heating than for cooling, but there is no real effect of the microstructure orientation. The main difference of coefficient is between the ferritic alloys $\left(10\right.$ to $\left.14 \times 10^{-6} \mathrm{~K}^{-1}\right)$ and the austenitic alloys $\left(14\right.$ to $\left.21 \times 10^{-6} \mathrm{~K}^{-1}\right)$.

The fast expansion observed for the austenitic alloys of this study in comparison with the ferritic alloys is in accordance with previous measurements, for example on pure iron [5] (for of course distinct temperature ranges). The presence of more or less high fractions in tantalum carbides, the thermal expansion of which is much lower than 
the matrixes ones (coefficient of only $6.3 \times 10^{-6} \mathrm{~K}^{-1}$ for $\mathrm{TaC}$ [6]) and even lower than for chromium carbides (10.1 to $10.6 \times 10^{-6} \mathrm{~K}^{-1}$ for $\mathrm{Cr}_{x} \mathrm{C}_{y}$ [6]), leads to a progressive deformation in compression of the matrix by the more or less connected interdendritic carbides when this matrix is mechanically weakened by the temperature become very high at the end of heating. This visco-plastic compression of the matrix accompanies the release of the tensile-stress affecting progressively the carbides during the first part of heating (induced by the increasing matrix-carbides interaction), previously observed for ternary alloys containing chromium carbides [7]. This goes on at the isothermal stage and results in a negative deformation of the sample after return to the room temperature. This deformation, which seemed being not really dependent on the microstructure orientation, was here enhanced in the case of the ferritic alloys, the bcc 姜matrix of which is mechanically less resistant than the more compact fcc 羊matrix.

Table 3. Deformations during heating, at the isothermal stage and during cooling

\begin{tabular}{|c|c|c|c|}
\hline \multirow{4}{*}{ Alloy } & \multirow{2}{*}{$/ /$} & average $\alpha_{250 \rightarrow 750}\left(\times 10^{-6 \circ} \mathrm{C}^{-1}\right)$ & \multirow{2}{*}{ average $\Delta \varepsilon / \Delta \mathrm{t}$ at $1200^{\circ} \mathrm{C}(\% / \mathrm{min})$} \\
\hline & & average $\alpha_{750 \rightarrow 250}\left(\times 10^{-60} \mathrm{C}^{-1}\right)$ & \\
\hline & \multirow{2}{*}{+} & average $\alpha_{250 \rightarrow 750}\left(\times 10^{-60} \mathrm{C}^{-1}\right)$ & \multirow{2}{*}{ average $\Delta \varepsilon / \Delta \mathrm{t}$ at $1200^{\circ} \mathrm{C}(\% / \mathrm{min})$} \\
\hline & & average $\alpha_{750 \rightarrow 250}\left(\times 10^{-60} \mathrm{C}^{-1}\right)$ & \\
\hline \multirow{4}{*}{ FeTa1 } & \multirow{2}{*}{$/ /$} & 10.5 & \multirow{2}{*}{-0.013} \\
\hline & & 10.5 & \\
\hline & \multirow{2}{*}{+} & 14.0 & \multirow{2}{*}{-0.014} \\
\hline & & 10.5 & \\
\hline \multirow{4}{*}{ FeTa2 } & \multirow{2}{*}{$/ /$} & 12.9 & \multirow{2}{*}{-0.007} \\
\hline & & 11.1 & \\
\hline & \multirow{2}{*}{+} & 13.2 & \multirow{2}{*}{-0.009} \\
\hline & & 11.1 & \\
\hline \multirow{4}{*}{ FeTa3 } & \multirow{2}{*}{$/ /$} & 10.7 & \multirow{2}{*}{-0.010} \\
\hline & & 10.4 & \\
\hline & \multirow{2}{*}{+} & 13.2 & \multirow{2}{*}{-0.013} \\
\hline & & 10.6 & \\
\hline \multirow{4}{*}{ FeNiTa1 } & \multirow{2}{*}{$/ /$} & 21.2 & \multirow{2}{*}{-0.002} \\
\hline & & 14.3 & \\
\hline & \multirow{2}{*}{+} & 20.9 & \multirow{2}{*}{-0.004} \\
\hline & & 18.2 & \\
\hline \multirow{4}{*}{ FeNiTa2 } & \multirow{2}{*}{$/ /$} & 20.8 & \multirow{2}{*}{-0.012} \\
\hline & & 16.0 & \\
\hline & \multirow{2}{*}{+} & 20.2 & \multirow{2}{*}{-0.003} \\
\hline & & 17.1 & \\
\hline \multirow{4}{*}{ FeNiTa3 } & \multirow{2}{*}{$/ /$} & 19.5 & \multirow{2}{*}{-0.003} \\
\hline & & 17.3 & \\
\hline & 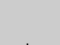 & 20.0 & 007 \\
\hline & + & 16.4 & -0.001 \\
\hline
\end{tabular}




\section{CONCLUSIONS}

Carbides in general and tantalum carbides in particular which are among the most stable at high temperature, are very useful for strengthening refractory alloys used at high temperature. However they can induce irreversibility for the thermal dimensional variations when temperature varies, which is furthermore obviously not isotropic although no clear dependence on the microstructure orientation was demonstrated. Phenomena similar to ones earlier observed for simple alloys reinforced with chromium carbides, were found here in the case of ferritic and austenitic iron-based alloys. They can be source of permanent dimensional changes after temperature cycles, and maybe of deterioration of the alloys at the microscopic scale.

PЕЗЮМЕ. В статті розглянуто шість сплавів, що базуються на залізі (феритні) та на нікелі та залізі (аустенітні), зміцнених карбідами $\mathrm{TaC}$ та їх термічне розширення між 100 та $1200^{\circ} \mathrm{C}$ для двох мікроструктурних орієнтацій. Представлені та обговорені нагрівання, ізотермічна та охолоджувальна ділянки на дилактометричних кривих. Термічне розширення феритних сплавів є менш вираженим ніж аустенітних. Стискальні деформації матриці призводять до напружень які поширюються на колонії карбідів. Важливість цього явища вбачається у впливі фази матриці на мікроструктурні особливості сплаву в цілому.

PЕЗЮМЕ. В статье рассмотрено шесть сплавов, которые базируються на железе (ферритные) и на ныкеле и железе (аустенитные), упрочненных карбидами ТаС и их термическое расширение между 100 и $1200^{\circ} \mathrm{C}$ для двоих микроструктурных ориентаций. Представлены и обсуждены нагревание, изотермический и охладительный участки на дилактометрических кривых. Термическое расширение ферритных сплавов есть менее выраженным, чем аустенитных. Сжимающие деформации матриц приводят к напряжениям, которые расширяются на колонии карбидов. Важность этого явления состоит во влияниии матричной фазы на микроструктурные особенности сплава в целом.

1. Bradley E. F. Superalloys: A Technical Guide // ASM International. - Metals Park, 1988.

2. Experimental and thermodynamic study of tantalum-containing iron-based alloys reinforced by carbides: Part I - Case of (Fe, Cr)-based ferritic steels // P. Berthod, Y. Hamini, L. Aranda and L. Héricher // Calphad, 31, 351 姜360 (2007).

3. Experimental and thermodynamic study of tantalum-containing iron-base alloys reinforced by carbides: Part II -Case of (Fe, Ni, Cr)-base austenitic steels // P. Berthod, Y. Hamini, L. Héricher and L. Aranda // Calphad, 31, 361 姜369 (2007).

4. Kurz W. and Fisher D. J. Fundamentals of solidification. - Trans Tech Publications, 1989.

5. Shaffer P. T. B. Plenum Press Handbooks of High-Temperature Materials $\mathrm{N}^{\circ} 1$. Materials Index // Plenum Press. - New York, 1964.

6. Samsonov G. V. Plenum Press Handbooks of High-Temperature Materials $\mathrm{N}^{\circ} 2$. Properties Index // Plenum Press. - New York, 1964.

7. Berthod $P$. Influence of carbides and of the dendritic orientation on the thermal expansion of Ni-base, Co-base and Fe-base simple cast alloys // Int. J. Mat. Res. (formerly Z. Metallkd.). - 2007. - 99. - P. 265-272.

Received 07.12.2009

Published in Fizyko-Khimichna Mekhanika Materialiv, Vol. 47, No. 3, pp. 46-52, May-June, 2011. 